\title{
"Employers could use us, but they don't": voices from blue-collar workplaces in a northern periphery
}

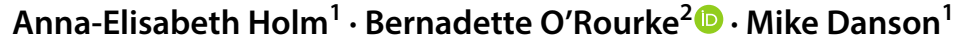

Received: 15 March 2018 / Accepted: 22 January 2019 / Published online: 15 May 2019

(c) The Author(s) 2019

\begin{abstract}
This article analyses labour market experiences of migrants of non-Nordic origin who have settled in the Faroe Islands, a small North Atlantic archipelago with a population of about 51,000 people. By examining the experiences of educated migrant workers who are employed in three different blue-collar workplaces: a cleaning company and two fish-processing plants, evidence is drawn from a cross-disciplinary study on language and migration in the Faroe Islands. This study explores the experiences of migrants in acquiring, using and becoming "new speakers" of Faroese and the challenges they face regarding labour market access and participation. In this article, framed within an ethnography of language policy, we highlight the institutional language policies which may be shaping migrants' experiences, and how migrants enact their own language policy decisions and practices on the ground. We focus in particular on internal communication and language management in the three blue-collar worksites, comprising views and voices of both employers and employees, on the language policies and practices observed in these workplaces, and on workers' views on language learning opportunities in blue-collar workplaces. Added to this, attention is drawn to implications of limited language learning opportunities in blue-collar jobs (which become the main barrier to accessing skilled jobs), to underutilisation of professional skills, and to long term implications of present macro- and micro-level language policies and practices affecting lived realities of workers of migrant origin.
\end{abstract}

Keywords Language learning · New speakers · Language brokering · Language policies · Multilingual workplaces · Migrant workers · Island communities · Barriers to skilled jobs · Pro-active inclusion policies · Migration to peripheral regions ·

Faroese · 'Small' language communities

Bernadette O'Rourke

Bernadette.ORourke@glasgow.ac.uk

1 School of Social Sciences, Heriot-Watt University, Edinburgh, UK

2 School of Modern Languages and Cultures, University of Glasgow, Glasgow, UK 


\section{Introduction}

"Employers could use us, but they don't". These were the words of Joanna, a young, well-educated woman of migrant origin who works as a cleaner in a company in the Faroe Islands. She was not referring specifically to her own employer, but to employers more generally who she sees as gatekeepers within professional sectors in the local labour market. Joanna ${ }^{1}$ speaks four languages and also understands basic Faroese. Before coming to the Faroes she held an administrative position in an international organisation, drawing on the skills she had acquired during her university education. Joanna seemed interested in her own social standing and in making money for herself and to support her family. As such she was keen to contribute to the local economy in the Faroes, drawing on her skills set. However, she expressed frustration about her employment experiences so far, linked in part to what she perceived as a poor grasp of Faroese, the official language of the Faroe Islands. This, she believed, was linked to limited opportunities to learn the language either formally or informally. Her low level of competence, she said had implications for her long-term prospects within the Faroese labour market which she believed neither recognizes foreign qualifications nor employees who are not fluent in the local language.

Joanna's story captures the interrelated contemporary phenomena that will be the focus of this paper: the dynamics of becoming a "new speaker" of a minoritized language in the context of migration and transnational employment. We use the "new speaker" concept as a lens to study individuals who did not learn a (minority/ minoritized) language (such as Faroese) through family transmission in the home, but instead acquired it through the education system or as adult learners, sometimes in the context of language revitalization projects or language policy initiatives (O'Rourke et al. 2015). A central area of concern in research on new speakers relates to the potential tensions around the legitimacy, authority, and authenticity awarded to different speakers ("old" and "new", "native" and "non-native") (O'Rourke and Ramallo 2013). A lot of the research on new speakers of minority languages has focused on the local population and the dynamics involved in acquiring and adopting a minority language as part of their linguistic repertoires. However, such processes entail another layer of complexity in the context of international migration where newcomers from outside the community can find themselves doubly-challenged by their outsider status, when it comes to gaining legitimacy and accessing resources. In the case of the Faroes, a further layer of complexity is discernible due to this region's bilingual situation comprising two small languages (Faroese and Danish) where the minoritized language, Faroese, is spoken by the majority population. This poses particular challenges, which are demonstrated in the section on the sociolinguistic landscape.

Work on other minoritized language contexts such as Catalan (Pujolar and Puigdevall 2015; Woolard 1998, 2016) and Quebecois French (Lamarre 2013), for example,

\footnotetext{
1 Joanna is a pseudonym.
} 
has examined the language practices and ideologies of new speakers from many different parts of the world and how they position themselves or are positioned by others as legitimate speakers. Bermingham and O'Rourke (2018) have observed that the linguistic competence of Galician new speakers of Cape Verdean origin is not always recognized by locals in the Autonomous Community of Galicia in north western Spain. Similarly, Caglitutuncigil's (2018) research on new speakers of Catalan amongst female African immigrants found that, while learning Catalan can open up new opportunities, the benefits of attending formal language support classes are often limited as the classes do not always or necessarily prepare them for language use outside the classroom.

In this article we examine the experience of international migrants in acquiring, using and becoming new speakers of Faroese and the specific challenges this brings with respect to labour market access and participation. These new speakers as transnational workers provide a lens through which the processes involved in accessing work can be explored, building on existing research around multilingual competence(s) in transnationally operating workplaces (see Duchêne et al. 2013; Heller 2011). Our paper also aims to contribute to the investigation of how language policies shape the lives of these new speakers and, in turn, the role that new speakers play as language policy actors on the ground (see Darquennes and Soler 2019).

\section{New speakers, mobilities and labour market integration}

Over recent decades, contemporary societies, including peripheral communities and remote islands (Danson and de Souza 2012), have undergone rapid social, cultural and linguistic change brought about by globalization, increased mobility, transnational flows, new technologies and a changing political and economic landscape (Blommaert 2010; Simpson and Whiteside 2015). These changes have had major implications for the ways in which we conceptualize the relationship between language and society in the 21st century. A new communicative order has emerged with new types of speakers, new forms of language and new modes of communication (O'Rourke and Pujolar 2015). The drivers for migration and these related developments have also made their way to the Faroe Islands (Samuelsen 2017), a small North Atlantic archipelago situated about halfway between Iceland and Scotland (Figure 1), with a population that had just reached 50,000 in 2017. In recent years, especially since the beginning of the $21^{\text {st }}$ century, these islands have experienced a rapid increase in in-migration (see Figures $2,3^{2}$ ) with people coming from different parts of the world, ${ }^{3}$ notably from the Philippines, Thailand, Russia, Eastern Europe and Africa, some as a result of multiple migrations.

Who are these newcomers, and why do they migrate to the Faroes? In fact, little is known about the language trajectories or professional experiences of these "new speakers" (O’Rourke and Pujolar 2015) who, as second language speakers of Faroese, adopt the language as part of their multilingual repertoires. The vast majority

\footnotetext{
2 Source: Statistics Faroe Islands: https://statbank.hagstova.fo/pxweb/en/H2/H2__B__IB03/.

${ }^{3}$ Statistics Faroe Islands, Census 2011: http://www.hagstova.fo/sites/default/files/pdf/oll-telja-vid.pdf.
} 


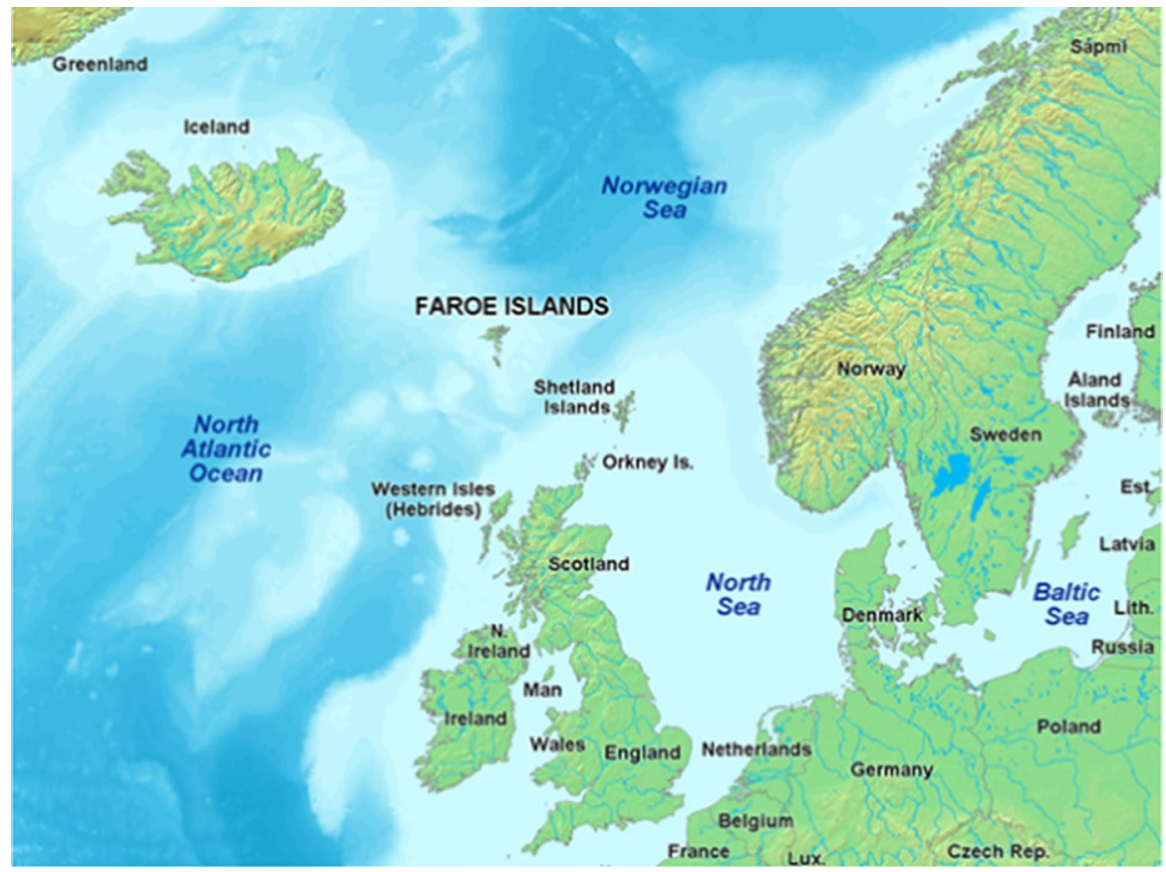

Figure 1 The geographical location of the Faroe Islands Source: https://commons.wikimedia.org/wiki/Atlas_of_the_Faroe_Islands

1400

In-migrants: Population by citizenship

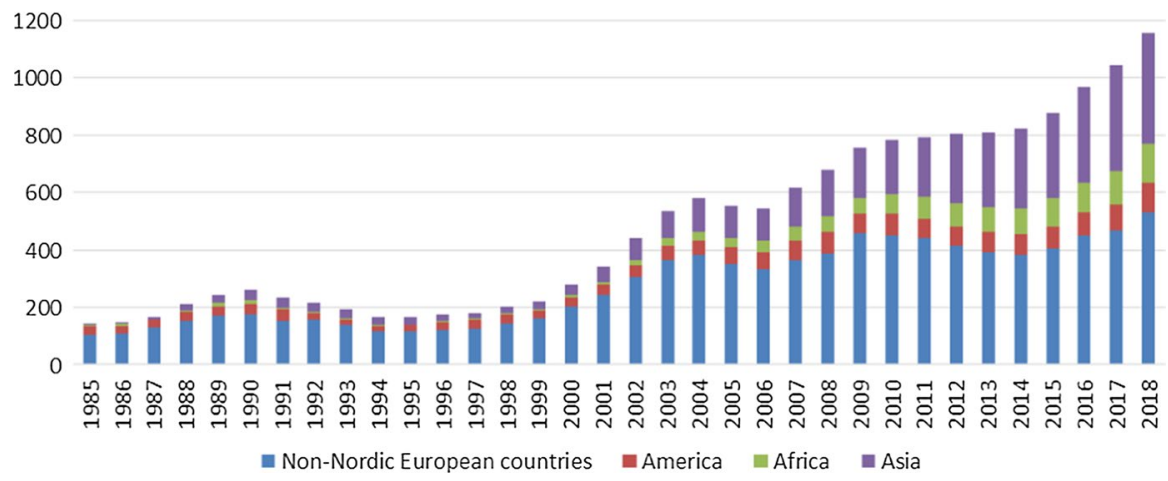

Figure 2 In-migration from 1985 to 2018 (Nordic countries are not included)

of those migrating to the Faroes come on work permits or through family reunification schemes as they have married local spouses. Joanna and other participants in our study had come from Eastern Europe, Africa, Asia and other Western European countries and have all chosen to make the Faroes their home. 


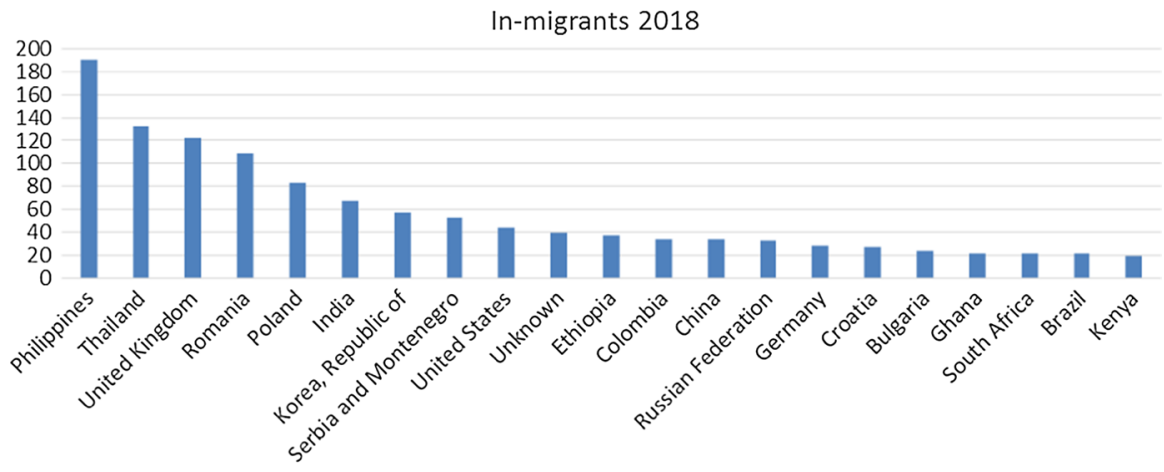

Country of origin

Figure 3 In-migrants' country of origin (top twenty in actual numbers by January 2018)

Language is key when it comes to accessing education, employment, social services and, ultimately, for community participation. Therefore, the acquisition of a new language for these migrants can affect the prospects of integrating into their host society and in fully contributing to its economic, social, political and community life. However, the processes whereby people learn new languages and become legitimate speakers of these languages are complex (Bourdieu 1977; Piller 2016; Simpson and Whiteside 2015). These processes are contingent on different factors, most of which are outside the control of the individual learner. These include age, background, learning environment, access to the target language and 'which hand one has been dealt in life' (Piller 2016). Piller further argues that language learning is a highly underestimated endeavour as it takes a long time to learn a new language as an adult and claims that "the ultimate outcome of second-language learning efforts is not purely an act of willpower or a result of the learner's personal choices" (2016: 49). In her research on immigrant women in Canada, Norton (2000) also questions dominant assumptions about language learning being a matter of willpower and motivation, and that "high levels of motivation did not necessarily translate into good language learning" (2000: 6).

In this article, we explore how the processes whereby people learn new languages are played out by social actors on the ground. We examine how communication is managed between employers and employees of migrant origin in blue-collar workplaces $^{4}$ in the Faroe Islands, what language policies are mobilized in these worksites, and what opportunities for language learning these workplaces provide as a means of career advancement in the local labour market.

\footnotetext{
${ }^{4}$ Here we use a broad definition of a 'blue-collar workplace' as being dominated by manual labour which may involve skilled or unskilled work in manufacturing, mining, construction and, particularly in this context, fish-processing and cleaning. Nevertheless, there will also be white-collar workers in such environments performing professional, managerial, and administrative work.
} 
To do this, we draw on insights emerging from a sociolinguistic study of language and migration in the Faroe Islands. This is part of a broader study ${ }^{5}$ which explores the experience of migrants in acquiring, using and becoming speakers of Faroese and the challenges they face with respect to labour market access and participation. ${ }^{6}$

As Duchêne et al. (2013) have noted, although many workers of migrant origin possess considerable linguistic resources, or what Moll et al. (1992) refer to as "funds of knowledge", they often remain in low-skilled jobs because of language barriers. While migrants can be found in the highly skilled sectors of the economy, our focus is on migrants in low-skilled jobs. In this article we will focus specifically on institutional language policies in three blue-collar workplaces dominated by such jobs, and the extent to which they shape the way these migrants enact their own language policy decisions and practices on the ground. Our aim is to understand the implications of such policies for (under)employment and the potential link this may have with the lack of language learning opportunities in such workplaces. In our study, we examine the implications of language policies which involve people with high level skills (including multilingual skills) in low-skilled blue-collar occupations and the potential challenges posed to their professional identity (see Gonçalves 2013; Norton 2000). The research outlined in this article presents an ethnographic account of how new speakers of Faroese navigate their linguistic trajectory as part of labour market integration. As such, it is closely aligned with recent theoretical and methodological developments in language policy and language planning (LPLP) research which actively incorporates discursive and ethnographic perspectives in the field of LPLP (e.g. Barakos and Unger 2016; Johnson 2009, 2013; McCarty 2011; Martin-Jones and de Costa Cabral 2018).

In what follows we examine the theoretical developments in LPLP before introducing the sociolinguistic landscape and language policies in the Faroes. Drawing on ethnographic fieldwork in the Faroes, we examine three key themes which emerged from our data: (1) internal communication, mediation and language brokering in the workplace; (2) the circulation of language policies in the workplace; and (3) the workplace as a site for language learning.

\section{The ethnography of language policy and planning in the periphery}

Academic discussions around language policy and planning (LPLP) have pointed to the multilayered nature of language policymaking (Barakos and Unger 2016; Blommaert et al. 2009; Halonen et al. 2014; Johnson 2009, 2013) and moved away from contrasting 'top-down' and 'bottom-up' poles of opposition

\footnotetext{
5 This research is part of a PhD project in progress (2016-2019) entitled "New Times, 'New Speakers' of Faroese and the Sociolinguistics of Labour Market Access: Challenges and Opportunities", funded by Heriot-Watt University and the Faroese Research Council.

${ }^{6}$ About two-thirds of the participants in the broader study, most of whom are in low-skilled jobs, have some form of tertiary or higher education. This is not dissimilar to other contexts. About two thirds of the workers of migrant origin coming to Scotland in the mid-2000s had some form of tertiary education or were university graduates (Brown and Danson 2008).
} 
(Canagarajah 2006). There is now a growing body of research which looks at how discourses circulate across the language policy cycle (Canagarajah 2006). As Canagarajah (2006: 158) explains, by looking at the full language policy cycle we are provided with "feedback on the diverse stages of a policy". This in turn facilitates greater focus on the ways in which social actors position themselves in relation to discourses as a means of opening up ideological spaces for the use of certain languages or linguistic varieties (Johnson 2009). In the case of new speakers of Faroese, the impact of language policy on the process of becoming and being competent in the local language has consequences for both authorities (i.e. language policymaking bodies and institutions) and individual migrants themselves.

Of particular relevance to exploring the complex relationship between LPLP and new speakers of Faroese is the ethnography of language policy (ELP), which aims to draw together the macro-level development and implementation of language policy and the situated negotiation of language policy by social actors on the ground. ELP sets out to examine "agents, contexts, and processes across the multiple layers of language policy creation, interpretation, and appropriation" (Johnson 2013: 44). As such, the main purpose of ELP is to move towards a resolution of the tension between critical theory's analyses of how power operates at a macro-level and the agentive creativity of individual speakers. In our case, this involves an analysis of the negotiation of power at institutional level and new speakers of Faroese themselves and as such presents an attempt to bridge the gap between the macro- and micro-level dimensions of social life (Hult 2010). ELP can thus be seen as a way of establishing connections between the different layers of language policymaking, be that at individual, institutional, national and supranational levels (Hornberger and Johnson 2007). At the same time, it allows us to unpack the social meanings tied to these interrelated processes. As McCarty (2015: 81) puts it, ELP "entails a view of policy as a situated sociocultural process: the practices, ideologies, attitudes, and mechanisms that influence people's language choices in pervasive everyday ways." Exploring how discourses circulate across multiple scales allows for a more critical assessment of how ideological spaces which foster the use (or non-use) of certain languages and ways of speaking are accepted or not (Johnson 2009).

Our specific focus on a small island community such as the Faroes provides a context in which the dynamics of peripheral multilingualism can be explored and as such adds an additional layer of complexity when it comes to understanding the language policy cycle. As a less traditional destination for in-migration, the Faroe Islands and other peripheral communities like this constitute regions where out-migration amongst the youth is so deeply embedded in people's peripheral and lived realities that one can talk of "a culture of migration" within these communities themselves (Hayfield 2017: 3; King 2009). Changing migration dynamics impact the language policy cycle. For a 'small' language such as Faroese, 'new circumstances' (Pietikäinen et al. 2016) have also been shaped by the complexities and transnational mobilities of globalised late modernity. While the acquisition of a new language has been widely investigated in urban, nationstate contexts, little attention has been paid to non-traditional contexts such as the Faroe Islands. The local language, Faroese, is the majority language in numerical 
terms but, as we will discuss in more detail below, another less widely used language (in this case Danish) plays an important role in both political and socioeconomic terms. Indeed, geographies are important as Pietikäinen et al. (2016) note. The meanings of what constitutes centre and periphery is not static and is constantly renegotiated. Further, much of the research on migration and migrants around the world has been undertaken in urban settings (though Britain 2012, 2016, discusses the so-called 'urban fetish' within variationist studies, while 'counter urbanization' is explored by Medda-Windischer et al. 2012; Danson and Jentsch 2012). Together these locality considerations confirm that there is a need to contextualise language acquisition within distinctive environments, such as the Faroe Islands.

In contrast, the body of research on migration to peripheral and rural areas is limited and remains neglected as a research topic (Medda-Windischer et al. 2012; Danson and Jentsch 2012), despite in-migration to peripheral areas increasing since the turn of the 21st century (see Cabral and Martin-Jones 2017 for a recent exploration of transnational migration to peripheral areas in a rural setting in Northern Ireland). Labour market experiences of international migrants to non-metropolitan and rural areas, in Ireland, Scotland, Canada and the USA, reveal factors that emerge as being particularly important in shaping the experiences of labour migrants to rural areas, including pay and working conditions and the significance of welcoming communities (Danson and Jentsch 2012). As we will show in the following section, the story of language policies and the sociolinguistic landscape of the Faroe Islands has been shaped by their small and geographically peripheral position. This has affected the dynamics of multilingualism in the community and the values attached to its different linguistic resources.

\section{The sociolinguistic landscape, multilingualism and language policy in the Faroes}

Since the Home Rule Act of 1948, the Faroe Islands have been a self-governing polity within the kingdom of Denmark (Hayfield 2017). The Home Rule Act ${ }^{7}$ stipulates that Faroese is the principal language, but it also states that Danish and Faroese shall enjoy equal status. Faroese, a west Nordic language originating from Old Norse, a language not spoken anywhere else in the world, is the language of the vast majority of the population in the Faroes, but in demographic and political terms, it is a minority or minoritized language within the state of Denmark and the wider Nordic region. With no written language until about a century and a half ago, today Faroese is considered to be a fully-fledged national language (Sandøy 1992; Holm 2003). As these islands have been subordinate to the Danish crown for many centuries, there is a long history of language contact (Petersen 2006, 2010; Weyhe 2015)

\footnotetext{
7 http://www.government.fo/en/the-government/the-home-rule-act/ Section 11: "Faroese is acknowledged as the principal language, but Danish shall be taught well and carefully, and Danish may be used as well as Faroese in public affairs".
} 
and asymmetrical power relations in socio-political terms regarding status and usage of Faroese and Danish, respectively. However, since the end of World War II, Faroese has gradually come to be seen as the 'legitimate' language of the nation of the Faroes. The vast majority of the Faroe Islanders have Faroese as their first language: 93.8\% according to the 2011 Census (Statistics Faroe Islands); they speak, read and write in at least two languages, Faroese and Danish, and many, especially the younger generation, have added English (and sometimes other languages) ${ }^{8}$ to their repertoire through compulsory education and mass media.

Indeed, multilingualism has always existed due to contact with Danish and other Nordic languages, but has become even more widespread now in the context of a globalized economy. As Sandøy (1992: 73) observed, the challenge for the Faroe Islanders when it comes to maintaining Faroese and ensuring the sustainability of this small language is how to manage "their necessary bilingualism or trilingualism without harming their first language". The presence of English has rapidly increased in the last couple of decades (Jacobsen 2012), being omnipresent through, for example, modern technology and mass media. The implications of this rapidly changing reality is, as expressed in public discourses on a daily basis, a major concern for policymakers, teachers and people engaged in language planning initiatives. Moreover, in recent years English has increasingly been used as a lingua franca with and among newcomers of non-Nordic origin. Nearly 100 different languages were identified as citizens' first language ${ }^{9}$ in the 2011 Census, indicating that the Faroes have become a society where multilingualism is increasing.

Faroese, however, is the main language used in all public domains and in both private and public workplaces. Nevertheless, many newcomers soon experience that learning Faroese is not always enough as accessing skilled employment often requires learning Danish too. Therefore, this dual obstacle adds to migrants' multiple challenges regarding language learning, mobility and labour market access. Although Faroe islanders may not view Danish as central to their linguistic identity (Mitchinson 2012), Danish continues to play an important societal role. For example, while Faroese is the main spoken medium used in education at all levels, including university, nearly $80 \%$ of teaching materials in post-compulsory education are still in Danish (Johannesarson 2018). The dominant (and often invisible on the surface) role of Danish through the means of written materials is also evident in many skilled professions and political areas that have not been devolved, such as immigration and border control. These realities constitute major obstacles that prevent migrant workers' progression from unskilled to skilled employment. Also, linguistic challenges in this particular context index complexities linked with challenges faced by small or minoritised languages in globalised late modernity (Pietikäinen et al. 2016) through lived realities and conditions on this specific peripheral linguistic

\footnotetext{
8 While English is a compulsory language for all pupils in secondary education, many young people at upper-secondary level choose to add other European languages as school subjects including Spanish, French or German.

9 Statistics Faroe Islands (Hagstova Føroya): http://www.hagstova.fo/sites/default/files/pdf/oll-telja-vid. pdf.
} 
market. In fact, the unprecedented social and demographic changes taking place due to the intensification of transnational population flows and the increase in labour migration (Blommaert 2010; Duchêne et al. 2013) are increasingly more visible in European peripheries such as the small Faroese labour market. These processes of change are not all new in substance, but "they are new in intensity, scope and scale" (Blommaert 2010: 1).

With regard to top-down language policy and planning for Faroese, an interventionist approach (Cooper 1989; Fishman 1991), predominantly based on prescriptivist, monolingual ideologies of purism (Thomas 1991), has both created milestones and tensions in policies and practices on the ground (Knudsen 2010). At present, public language policies are managed by a national Faroese Language Board, which was stipulated by a law passed by the Løgting (the parliament of the Faroes) in 2012 and given authority in language questions. The main task of the Language Board is to develop and protect the Faroese language and to give advice and make decisions on language questions (Language Board $\mathrm{Act}^{10}$ ). This includes developing new terminology in collaboration with different trade groups and professional fields, giving advice on language use to public institutions, and arriving at conclusions in relation to language questions. Paradoxically, and in spite of a changing sociolinguistic landscape, there is no mention of bilingualism, multilingualism, management of linguistic diversity, new speakers of Faroese, or of the development of Faroese as an additional language in the parliamentary act stipulated for the new Language Board. However, in a report entitled Málmørk (2007), meaning language boundaries, language policy initiatives regarding integration of newcomers are mentioned briefly stating that immigrants "should have the right and the opportunity to learn Faroese while their own language is supported and granted conditions to develop at the same time" (Mentamálaráðið 2007: 85, authors' translation and emphasis added).

Still, more than a decade after the publication of this ministerial report, national language policy responses to the dynamic diversity associated with in-migration in recent years are scarce. While the acquisition of Faroese on the one hand is promoted in public discourse as a sine qua non of integration and access to professional jobs, as recognised and explored in a 1-day seminar in Tórshavn, in August 2017 (see Footnote 13), it can be argued that the lack of governmental policy responses to the diverse language learning needs of adult migrants on the other hand contribute to what Heller (2011) would describe as unequal access to the local language and skilled jobs in this particular labour market.

In the Faroese context, the discussion of language as capital (Bourdieu 1977, 1991; Heller 2007, 2011) is also highly relevant to the language policy situation in the sense that migrants who settle in these islands need to have access to opportunities to invest (Norton 2000) in local linguistic capital, which-as emphasised already - is key to skilled jobs in the local labour market and to opportunities to engage in daily interactions with other workers. However, such investment options are scarce, especially outside of the Faroese capital city where two of the research sites presented in this article are based. The main reasons for this include a lack of

${ }^{10}$ Løgtingslóg nr. 59 frá 15. mai 2012 um málráð, sum broytt við løgtingslóg nr. 104 frá 13. juli 2017. 
political priorities and the fact that Faroese as a foreign or additional language has not been developed, nationally coordinated or formalized (av Skarði 2018). Short courses in evening schools in a few of the larger villages on the islands are available in the winter time, usually taught by local Faroese teachers who are used to teaching Faroese as a subject to first language speakers but are not professionally trained in teaching it as a foreign language. In most cases, however, these courses are at a very basic beginners' level. This means that having the opportunity to study Faroese at different competence levels (such as the CEFR ${ }^{11}$ ) is literally non-existent. Neither is there the option to attend integration training programmes or targeted courses for specific purposes that exist in other Nordic countries. Since 2014, intensive daytime courses have been offered through the evening school in the capital (av Skarði 2018), which indicates some improvement. This notwithstanding, as availability of language courses spans from limited to non-existent in most municipalities, access and opportunities to invest in local linguistic capital pose serious challenges to most migrants wishing to acquire Faroese at a level that makes progression into skilled employment possible. As Duchêne et al. (2013: 5) suggest, language is not only a practice but also a resource that can have both symbolic value and exchange value in a market economy, and Faroese is no different in this respect. In her discussion of the Australian linguistic market, Piller (2016: 66), however, has cautioned against drawing simplistic conclusions regarding the value of English as a resource for moving into employment. As she puts it: "the assumption of a straightforward relationship between English language proficiency and access to the job market is overly simplistic", thus implying that other factors, including other forms of discrimination, are involved. While similar conclusions may potentially be drawn about the use of Faroese, arguably, the dynamics at play in the context of an international language such as English in Australia are not the same as a small minoritized language such as Faroese which suffers from a lack of resources (e.g. with regard to written resources, visibility of Faroese in information and communication technology, media and professional fields) compared to its contact language, Danish. In addition, the Faroes are constrained by a small labour market that struggles to employ its own graduates in skilled jobs, with relatively few professional fields (Føroya Landsstýri 2013; Hovgaard and West 2003). The reality is that many skilled jobs require competence in Danish in addition to Faroese, which only adds to the barriers migrants face in terms of accessing skilled professions (Útlendingastovan 2016). As a result, labour market mobility is greatly limited for both skilled and unskilled newcomers.

The Faroe Islands, along with Greenland, constitute the periphery of the Danish state, and of the Nordic region, in terms of their geographic isolation, their topographies, political status as self-governing sub-state territories, small populations, 'small' languages and material resources. Pietikäinen et al. (2016: 195) argue that "peripheries can and should inform our general understanding of globalisation in all its social and sociolinguistic dimensions". They further argue that sociolinguistic theory can be enriched with more views from peripheries as both centre and peripheral views are needed to give a more nuanced picture of contemporary

11 https://www.coe.int/en/web/common-european-framework-reference-languages/level-descriptions. 
Table 1 'Voices' quoted (or referred to) in the data analysis section

\begin{tabular}{|c|c|c|c|c|}
\hline Name & Origin & Education level & Position & Interview language \\
\hline Manager & Faroe Islands & Vocational education & $\begin{array}{l}\text { Manager of cleaning } \\
\text { company }\end{array}$ & Faroese \\
\hline Joanna & Africa & Masters & Cleaner & English \\
\hline Juliana & Eastern Europe & Bachelor & Cleaner & Faroese and English \\
\hline Supervisors (2) & Faroe Islands & $\begin{array}{l}\text { Compulsory educa- } \\
\text { tion and vocational } \\
\text { training }\end{array}$ & $\begin{array}{l}\text { Supervisors/fish- } \\
\text { factory workers }\end{array}$ & Faroese \\
\hline Milana & Eastern Europe & Vocational education & Fish-factory worker & English \\
\hline David & Eastern Europe & Vocational education & Fish-factory worker & English \\
\hline Lea & Europe & Bachelor & Fish-factory worker & Faroese and English \\
\hline Helena & Asia & Bachelor & Fish-factory worker & English \\
\hline Anita & Asia & Masters & Education professional & English \\
\hline
\end{tabular}

The two fish factories are aggregated here to preserve anonymity of the participants

sociolinguistic processes and language policies. Our focus on the dynamics of multilingualism in the Faroe Islands contributes to this framework.

\section{Methodology and fieldwork sites}

As we outlined earlier in the paper, our interest is in understanding how communication is managed between workers and employers in blue-collar workplaces, what language policies are mobilized, and what opportunities for language learning are provided in these workplaces. This study is framed within the ethnography of language policy. As such it draws more broadly from within sociolinguistic ethnography (Heller 2008, 2011). Drawing on this approach, we link local practices and values with wider social processes (such as globalization) (Heller 2011; Blommaert 2010) and also with wider language ideologies, such as those of power, authority and authenticity (Gal 1989; Irvine and Gal 2000; Woolard 1998, 2016).

Most participants in our study are employees in blue-collar workplaces in the Faroe Islands. These include a cleaning company and two fish-processing plants, located in three different geographical locations. Table 1 above gives an overview of the participants reported on in the data analysis section. All but one participant in the study (Anita see Extract 4), are blue-collar workers. Interviews with both bluecollar workers and managers in these local workplaces, accompanied by field notes and observations made during guided visits to the factory floor, and informal discussions with workers during coffee and meal breaks in the factory canteen, provided insights into the companies' internal language policies and practices. The ethnographic interviews with participants lasted between 30 and $90 \mathrm{~min}$ and were undertaken during recurrent fieldtrips lasting from 2 weeks to 3 months periods over the first two years of the study. Observations, interviews and casual conversations with workers at the fish-processing plants and in the cleaning company took place 
on different days throughout the field visits, and more intensely during short-term employment as a fish-factory worker in the third year of the project. The types of observations comprised, for example, of workplace routines and working conditions (such as observing people on the factory floor), bilingual signage posted within the factory premises, message boards, observations of who sat with whom during breaks, language use during breaks, and communication between managerial staff and workers. Informal conversations with employers and workers during coffee breaks were casual and brief, whereas interviews undertaken on factory premises or in participants' homes provided opportunities to go into more depth. The main focus in these conversations was on participants' experiences with language learning, both within and outside the workplace context, access to the Faroese language, attitudes towards the participants' use of languages in the workplace, perceived barriers to skilled jobs and future aspirations.

In addition to fieldnotes, observations and informal interviews which were recorded and transcribed, other data were also gathered during fieldtrips. These for example included newspaper articles, radio and television programmes, the present Government's coalition agreement, policy documents, brochures, photographs of bilingual notices in workplaces, notes from a stakeholder event on "Language, Inclusion and Labour Markets", ${ }^{12}$ and feedback from participants at this stakeholder event.

Research participants were contacted and recruited through different channels including a trade union for unskilled workers, personal social networks, careers and guidance counsellors, the national integration coordinator, and either directly by approaching workers in the workplaces or through their managers and supervisors. The first author of this article is from the island community itself, speaks Faroese as her first language, and has experience as a former fish-factory worker. She contacted workplaces and undertook all interviews. More recently she worked for a period of time in a fish-factory in order to follow some of the participants into the workplace and thus get a better understanding of the questions that this study explores. The researcher's goals, assumptions and procedures were made explicit in the interaction. We agree with Norton (2000: 61) who underlines that "researchers need to be particularly cognizant of the unequal relationship between researcher and researched since such subjects, new to a society, have few institutional protections and are frequently vulnerable and isolated!". This requires being committed to the importance of building a dialogic researcher-participant relationship and taking on board critical reflexivity with respect to positionality and fieldwork (Jaffe 2012).

\footnotetext{
12 A one-day seminar (organised by the first author in collaboration with the national integration coordinator) in Tórshavn, in August 2017. This brought together new speakers of Faroese (immigrants), policymakers, researchers, educators, social partners and other stakeholders to discuss pathways for better inclusion in society and successful labour market inclusion. The main focus was on migrants' experiences and challenges regarding language learning and labour market access in the Faroe Islands. The programme included presentations by all three authors, by newcomers to the islands and discussion rounds on three themes that are apparent in the data and findings from the broader study that this article draws on: Faroese as a foreign language; labour market flexibility; and adult education (including lifelong guidance and recognition of prior learning).
} 
With regard to the cleaning company, contact was made with possible research participants through the departmental manager of this company, and in two fishprocessing plants, a 'way in' was via telephone contact with the women who were supervisors, also referred to as production managers. Prior to interviewing any employees in these sites, conversations with the three company contacts took place where there was the opportunity to explain the aims of the study, and the purpose of conversations with some of their employees. Of particular interest was the management of linguistic diversity in the workplace and what communication strategies they use with employees who do not understand the local language.

Given the small society and small size of the population in the Faroes, people and workplaces are easy to recognize and therefore difficult to anonymize. In cases where individuals could be identified, to maintain anonymity some details are removed, including participants' country of origin, ${ }^{13}$ first language and geographical work location. In both fish-processing plants, a room was set aside to conduct the interviews. It was made clear during introductions that the researcher was not in any way connected to their employer. In other cases, the participants were met at their workplace and then arrangements were made to hold the interview elsewhere, outside of work hours. All of the employer interviews were held at their workplaces. The interview language, Faroese or English, or both, was decided upon by the interviewees, depending on their preference and perceived fluency in Faroese.

\section{Internal communication, mediation and language brokering in the workplace}

Faroese was the main language used in all three of the blue-collar workplaces visited, but with those not understanding Faroese, English was used as the lingua franca. For example, in both fish-processing plants, there were notices in both Faroese and in English on the walls, on information screens, in toilets, and in the cafeteria. All of the employers interviewed said that they did what they could to make themselves understood in their communication with non-Faroese speaking staff. One of the supervisors we interviewed said that she always tries speaking in Faroese first, but if a worker does not understand her, she uses English, although she assessed her own English as being very limited. In exceptional cases, she asks another worker who functions as a broker for help in communicating a message to an employee who neither understands Faroese nor English. While most work on language brokering has emphasized child brokering for their parents (e.g. Tse 1996; Del Torto 2008; Lazarevic et al. 2014), adult brokers are identified in the work of Gonçalves and Schluter (2017) and Piller and Lising (2014) or as mediators in Del Percio (2015). In contrast to Gonçalves and Schluter's (2017) study, where the owner of a cleaning company serves as the main language broker between her English-speaking clients and her primarily Portuguese-speaking cleaners, the Faroese study shows that it is

\footnotetext{
13 The only country of origin mentioned in this article is the Philippines. Filipinos constitute the largest number of immigrants, i.e. in the $100+$ category. See Figure 2.
} 
the workers themselves who serve as brokers. As one of the fish-factory supervisors pointed out, asking another worker to help mediate understanding only happens very occasionally, whereas in the cleaning company it is a multilingual cleaner who regularly serves as a broker and is employed (and paid accordingly) to communicate with staff who speak neither Faroese nor English.

According to one of the two supervisors interviewed at the fish-factories, most workers respond to her simple questions and work-related instructions in Faroese. The other supervisor said jokingly that sometimes she needs to use "body language" or some form of self-invented "sign language" in order to mediate communication at her workplace; this usually turns out quite well, according to her, as much work in fish-processing plants can be demonstrated without speaking (Hewitt 2012). This was confirmed by David, a fish-factory worker from Eastern Europe, who said about a fellow worker who neither understands Faroese nor English that "she doesn't need language" to do what she does in the factory.

Based on fieldwork observations of casual interactions between workers, and conversations with fish-factory workers and supervisors, workers at fish-processing plants would seem to draw on different language resources in the workplace. During coffee and lunch breaks, some workers prefer to sit together with colleagues who speak the same language. This is similar to what Piller and Lising (2014) found with their meat factory workers. Others were observed to sit at tables where people have mixed backgrounds, and therefore use English as a lingua franca, while others try to join Faroese speakers in order to practise speaking Faroese. As highlighted by Milena, a worker from Eastern Europe eager to learn Faroese: "I always sit with Faroese people, and they always want to speak with me. If I don't understand, they tell me in English". There did not seem to be a fixed arrangement about who sits where or who speaks with whom, but there did seem to be a habit of sitting with the same colleagues during breaks. This was later confirmed by many of the local Faroese workers we spoke to. Helena, a Filipino, who has been in the same fish-factory for 7 years, confirmed this by saying that she always sits with other "Filipinos and surrounded with Asians" where they use what she described as different dialects, along with Tagalog and English. When asked about communicating with Faroese workers, Helena added that some older Faroese workers do not understand English, so "you have to try your best to speak Faroese to them". However, there was a sense that language policies and practices in this workplace attempted to be inclusive, for example through written information to staff in both English and Faroese, through foremen's adaptive language practices, and in terms of non-interference in people's conversations if, for example, a whole group of Thai or Filipinos sit together, which is common. The breaks therefore seem to be workers' 'free time' to communicate with whom they like and in their language(s) of preference. This is very different to what was found in a recent Danish study where ethnic minority employees in a supermarket were criticized for speaking a foreign language during breaks in the canteen and for not upholding the 'Danish language only' policy of the company (Thuesen 2017).

At the cleaning site, the manager introduced the company as follows: "This is a Faroese company, so we must speak Faroese". However, when asked directly 
about the company's internal communication, the language practices that he described and supported were highly flexible and multilingual. As the following example would seem to show, this particular employer employs multilingual strategies in one of the training courses which he runs for staff on quality issues in cleaning (e.g. personal hygiene, how to protect oneself from bacteria, what soap or chemicals to use for different purposes, surfaces, etc.).

This particular course is a full-day workshop which he runs jointly with two or three employees of migrant origin. These co-instructors are experienced cleaners who work in the company but are also competent in different languages. As part of the course, the manager has also prepared a booklet and a PowerPoint presentation in English and Faroese that participants take home with them. That way, he says, they could study and compare Faroese and English terminology related to the issues being discussed. In the small groups that he teaches he uses both Faroese and English. He highlighted examples where they have Russians and Polish speakers as well as workers from other Eastern European countries who understand Russian, but who understand neither Faroese nor English. In such cases, when English does not work, it is a Russian-speaking employee who translates, communicates with participants, mediates content and works with the Russianspeaking cleaners. This is a company that has employees from 24 different countries; often they manage with English as a lingua franca, but not always. To cope with that challenge, the company has employed one of their multilingual staff to manage communications. As this is a compulsory training course for cleaners, participants need to show that they understand what the topic is about by engaging in tasks related to the topics in question. To ensure that all participants can demonstrate their understanding and thus pass the course, he employs a small multilingual team consisting of two or three staff who are cleaners employed in this particular company. This was later confirmed by a multilingual employee in the same company who, in addition to part-time cleaning, works as a communication officer and language broker; this is a cleaner who understands Faroese and is fluent in at least three non-Nordic languages and can thus mediate communication with a relatively large number of cleaning staff. Interestingly, in contrast to what Duchêne (2011) and Duchêne et al. (2013) report with regard to how the linguistic skills of migrants are utilized by powerful companies without workers deriving any benefits from them (e.g. in terms of salary or professional mobility), these cleaners receive good pay for the ad-hoc translation services they provide. For instance, one cleaner gave an example where she worked as a Russian interpreter for a particular assignment for the cleaning company. She told of how her boss gave her "a good bonus", although she did not want to reveal exactly how much she was paid.

It would appear that this manager gave some recognition to the multilingual skills of his employees and seems to see their skills as assets to the company. Simultaneously, he emphasized that he was running a cleaning company, and therefore did not have higher skilled jobs to offer, except occasional individual tasks as described above. The shifting role that the couple of cleaners take on as assistant instructors may be described as "language brokering". According to Tse (1996), quoted in Gonçalves and Schluter (2017: 243), "language brokers facilitate communication 
between two linguistically and/or culturally different parties. Unlike formal interpreters and translators, brokers mediate, rather than merely transmit, information".

Altough formally no prior knowledge of Faroese is required of these blue-collar workers to carry out their tasks, these examples show that much language work and language brokering is going on in the cleaning company to ensure communication between employees and the employer, suggesting there is an implicit language policy in place within the company.

\section{The circulation of language policies in the workplace}

As illustrated in the previous section, language practices and policies in all three workplaces would seem to be multilingual to varying degrees. None has a covert or written language policy, but the agentive creativity of individual speakers surfaced in interactions between workers and managers. This is evidenced by references to the multi-modal practices they employ, drawing on creative strategies such as their own 'invented sign language' as emphasized by the supervisors interviewed in the fish-processing plants, and by employing multilingual teaching assistants in the cleaning company. Therefore, both management and staff would seem to draw on different language resources in order to effectively mediate communication in the place of work.

The manager in the cleaning company admitted that communication with some employees was challenging, especially if people did not understand English. Therefore, his company decided to establish what the manager called a "Faroese school" which delivers beginners' and intermediate courses on a weekly basis. That initiative may be seen as a form of language policy being enacted. In the following excerpt, the manager describes the purpose of this initiative and comments on the outcome so far:

\section{Excerpt 1}

Manager: We decided to start a school. It wasn't only about language issues, but perhaps focusing on culture was equally important, how they (employees) understand Faroese people.... So actually, it started with that, and it has been really beneficial for us as a company that they attend school once a week.

Elisabeth: In what way do you see the benefits from you spending resources on this (i.e. work-based Faroese language courses)?

Manager: It's like when you're an employee, and you invest in human resources, then you get something in return. That is, it costs money of course, it does, but then on the other hand, you give something to your employees and they're of course benefitting from that. For us it has meant that we communicate much better now... I think we gain a lot from it.

Elisabeth: What is the purpose? 
Manager: This should be a better place to be at, we want that, that everybody is thriving.... Just something like being at a coffee break, and being able to understand conversations, that makes a big difference for an individual's wellbeing.

According to the company manager, the main reasons for offering work-based language courses are to give employees insights into the Faroese language and culture, to focus on workers' well-being and to improve cleaners' communication skills in Faroese in order to ease communication between the employer and employees. What he achieves in return is more satisfied workers. Such provisions in language policy and ideology have an effect on both the workplace and its workers as employment of a diverse labour force has major linguistic implications. While such strategies, as depicted in extract 1 , have the goal of being inclusive and providing support for workers in the acquisition of the local language, creating thriving blue-collar workers does not necessarily contribute to workers' progression on the local labour market. As will be demonstrated in the next section, the very nature of the type of blue-collar work depicted in this article has very little to offer migrants in terms of acquiring the local language, and therefore carries with it implications regarding long-term underemployment.

\section{The workplace as a site for language learning}

The issue of language learning — or rather the lack of language learning opportunities-in the workplace and in society was a topic of main concern among several interviewees. In this section, a number of examples will be given that shed light on participants' views on language learning in blue-collar workplaces.

Joanna, who we introduced in the opening paragraphs of the article, described cleaning as "a limiting job". She explained that the only time cleaners have people to interact with is when a customer requires " cleaning), then up to ten people clean together. She says: "The truth is that except for [name of company] that recognizes foreigners, the experience here is sad. We have education. Employers could use us, but they don't'. The employers she refers to here are those who are in charge of skilled and professional positions; her comments are based on her own experience as she has applied for several professional jobs without any success.

Joanna acknowledges that there may be cleaners who are satisfied with their jobs and with the flexible hours and the pay. She gave examples referring to some of her friends who are well-educated but who have decided to stay on in cleaning jobs:

\section{Excerpt 2}

Joanna: I really don't like when foreigners just sit and say we'll clean. Really, people are engineers, doctors, nurses... Some friends of mine are educated and they will never choose a professional job 
Elisabeth: They will not choose? Why?

Joanna: They are comfortable with cleaning

Elisabeth: Comfortable with cleaning? ...

Joanna: Yes. And they say it takes care of their bills, and it's okay. Like I say, everybody has their own goal, agenda

Here, Joanna conveys her frustration with fellow cleaners whom she describes as having given up on finding professional jobs and thus stay on in cleaning jobs for years on end. In her view, they end up becoming complacent and comfortable with cleaning. She does not elaborate on why this happens but, throughout our conversation, she was highly critical of the political authorities who she said did not have adequate infrastructure in place and did not offer intensive language courses suited to individual needs to allow newcomers to advance their careers. Her frustration is particularly strong when she says that: "If only foreigners could also be told that they shouldn't be comfortable with the fact that they can't speak Faroese and "Tað kemur" (it'll come), I really don't like that". "Tað kemur" is a Faroese expression that Joanna despises hearing. Implied in the expression is a laissez-faire attitude, a message to be patient, because eventually 'it'll come', meaning things will improve in the future, but it takes time.

Generally, Joanna was critical of the fact that migrants like herself, who are wellqualified, have no other choice but to clean or undertake other types of unskilled work, that they do not get the opportunity to use their professional skills within this local labour market. She is highly critical of well-educated migrants getting stuck in cleaning or other low skilled jobs for years for a wide range of reasons that in her view are mainly linked to 'not being fluent in Faroese or not knowing Danish'. She is equally concerned with the further implications of not being able to use her professional skills, of the long-term impact of underutilisation of one's educational qualifications. In this respect, Duchêne and Pietikäinen ${ }^{14}$ have argued that "Losing one's permanent position, relatively high status, etc. and again becoming a real beginner in relation to both language and career is a weighty decision and also a challenge for one's professional identity. Not being able to communicate like a professional may mean not being a professional anymore" (2017: 5).

Joanna has applied for several jobs that would match her skills, which include languages, communications and human resources, even offering to be an unpaid intern in a company simply to be able to make use of and to demonstrate her skills. But, she is frustrated that she has not even received a reply from these companies, and this is the cause of stress and discouragement. Similar to many other women of migrant origin, Joanna has moved to the Faroes because she married a man from these islands (Piller 2002; Gonçalves 2013; Breger and Hill 1998). She wants to fit in, get a job where she has opportunities to improve her proficiency in Faroese, to be included and contribute to this society with her skills, but her account tells of the many obstacles she faced along the way.

\footnotetext{
${ }^{14}$ Report on Workers as new speakers (WG3), Collaborative final report: http://www.nspk.org.uk/image s/WG3.pdf.
} 
Joanna then reflects on her role as a cleaner, sharing her dissatisfaction with the job where improving one's proficiency in Faroese is not an option. She describes the pain she feels when thinking about her professional past as a communications officer in an international organisation and worries about her prospects for the future. Her account points to the linguistic isolation and loneliness she experiences in her current job, which she finds both delimiting and demotivating:

\section{Excerpt 3}

Joanna: For me I use that time, like for my time.

Elisabeth: Ok?

Joanna: Yeah, so...

Elisabeth: Thinking time?

Joanna: Yeah. Thinking time. In the beginning I used to cry, because coming from where I have come from, the background when it comes to work, employment. Before I worked in the office and I was thinking, I was feeling, I was feeling that I have so much energy, I have so much knowledge, that I'm just, it's going slowly, you know...... So, I use that time to think and reflect. Will this be my life? You know? Am I going to do this for the rest of my life? And if I come home I complain, my husband tells me don't work. You can sit at home, I can take care of you. It's not a must, you know?

Elisabeth: But it's not satisfactory for you

Joanna: But it's not

Elisabeth: A well-educated woman like you

Joanna: to just sit there, you know

Moreover, as pointed out by Joanna above, and as previously demonstrated by Strömmer (2016) who shadowed a cleaner in Finland for a number of weeks, there are very limited language learning opportunities in a cleaning job as workers are mostly on their own after regular working hours, and indeed, also during their actual working time. Many cleaning jobs are language-marginal positions where cleaners work in isolation for hours, days and even weeks on end. The same applies to work at fish-processing plants where it is almost impossible to speak due to the noise from the machines. Talking about her own fieldwork in a factory, Heller (2011: 50) states that "looking at language on the factory floor made no sense: the noise from the machines was so loud that most of the workers wore earplugs". The same applies to the two fish-processing plants where this fieldwork was conducted; it is only during breaks that workers have a chance to engage in conversations and, as breaks are short, conversations and so opportunities to learn Faroese are limited. As Lea said in relation to her experience in a fish-factory, "It was not a job where you could learn Faroese.... you're just cutting fish, you don't talk to anybody".

Although Joanna does not like cleaning, and sees it as a waste of the resources and skills that she possesses, she speaks highly of the company she works for. She has participated in the language classes the company provides. It supports the cleaners' language learning efforts, she says, it is motivating and gives some insight into the local culture and society. However, she underlines that "After 
class we're alone. Cleaning is a lonely job". Those employed to teach these workplace classes are teachers who teach Faroese mother tongue classes in local secondary schools. These classes are offered once a week to employees who can benefit from this if they wish early in the afternoon when most cleaners have breaks in between assignments.

Another cleaner, Juliana, who says that cleaning is not actually her dream job but, compared to her previous work at a fish-processing plant where there was no flexibility, cleaning is much better and much more flexible. Also, she underlined that the pay is very good in comparison to wages in her country of origin. Juliana has no ambition to try for another job, partly due to her limited fluency in Faroese and no knowledge of Danish, but also because her priorities are being at home in the afternoon when her children finish school. Cleaning gives her that flexibility. But, she agrees with Joanna that cleaning does not provide opportunities for language learning when at work.

While workers in the cleaning company are given at least some support for language learning, consisting of classes a couple of hours a week, that is not the case in the fish-processing plants. Added to that, these factories are in geographical areas where no Faroese language courses are available or when they are, they are only for beginners. This lack of access to language learning courses aimed at different needs and competence levels was identified by several interviewees as a major obstacle to improving newcomers' opportunities in the labour market. This is illustrated, for example, by Helena, from the Philippines, whose dream is to become a nurse. She has considered moving to the capital where the evening school offers intensive daytime courses, but this is not a realistic option for her as she has children, parents to support back home, bills to pay, and a husband who works at sea for weeks at a time. When she found out that most books and materials are in Danish when studying for a nursing degree at the University of the Faroes, although the courses are taught in Faroese, she sees that dream as being very distant and too difficult to pursue. In contrast to the capital city, where she lives, in the periphery within the periphery, there are no courses at different competence levels that will help her move to an advanced level in Faroese and to pursue her ambition. In her words:

Some teachers are offering some English language foreigner people to learn Faroese, but it's only for a couple of months, and it's not really that serious, because we only meet one time a week, so it's not so good.

To conclude this section on language learning in the workplace, or more broadly on what it is like being an educated person who happens to be a migrant who has to adjust to a new place, language and culture, Anita shares the following description of this challenging experience:

\section{Excerpt 4}

What amazed me most was that when I went out of the home I was suddenly an illiterate person, that was a shock. I understood nothing, you know. I was a 
child groping to be heard, to be able to express myself, and it's...That for me was the shock, I call it an intellectual shock, I don't call it a cultural shock. Because the fact that people looked different, that the food was different, didn't bother me one bit. Eh, but,.. this struggle to express myself, to have my voice heard, to be a meaningful member of a spoken community, that - when it's not available, it distresses you. ...But here I'm nobody, I have to start from scratch. I think that was the greatest shock.

While not a blue-collar worker, but someone who managed to succeed in the local labour market, we chose to quote Anita in this section as she captures quite succinctly the essence of the challenging conditions that many migrants recounted that they were facing in relation to learning a new language. This is in line with what Block (2004) refers to as 'critical experiences'. In this extract, Anita narrates the transition from having come from a professional job in her country of origin to becoming a real beginner in relation to both a new language and career in a new context. This feeling is further illuminated by her expression of being "nobody" and of having "to start from scratch" (Bhugra 2004; Christensen 2016).

What our study seemed to show was that opportunities for language learning in blue-collar workplaces were scarce and even after several years in the workplace, many remained in a "starting from scratch" phase. Added to this, was the challenges associatiated with becoming a new speaker of a minoritized language, such as Faroese, in a multilingual context like the Faroe Islands, where Danish is a co-official language. The lack of language planning and language policy initiatives raises questions about how languages (in our case, Faroese and Danish), can act as tools for exclusion in the local labour markets (see also Bermingham and Higham 2018 in the case of Galician and Welsh).

\section{Discussion and concluding remarks}

This paper has highlighted how internal communication and language management functions in three blue-collar workplaces, the language policies and practices observed, and workers' views on lack of opportunities for language learning in these workplaces. Insights have been given of the companies' internal language policies and practices on the ground, multilingual realities, and of what Gonçalves and Schluter (2017: 261) aptly describe as "the complexities of individuals' sociolinguistic realities within a given community of practice, such as a multilingual workplace setting".

As Anita says, it all comes down to being a meaningful member of a spoken community, which implies being understood and respected (Extract 4) Simpson and Bradley (2017). However, what characterizes the lived experiences of educated migrants are the loss of professional identities, immense obstacles in the path towards labour market mobility, and lack of support in overcoming these obstacles. The lack of fluency in the target language combined with limited language learning opportunities therefore become the main barriers to accessing skilled jobs. On the one hand, 
workers need a job in order to learn the local language and to sustain themselves but, on the other, the only jobs available to newcomers who do not know the local language are the type where opportunities for language learning range from being literally non-existent to limited. The question is how to break this circle and turn 'talented waste' into 'talented gain'.

Similar challenges with migrant workers in other countries have been observed. In the Scottish context, "using people with very high skills in low wage occupation is a huge waste of valuable human capital" (Brown and Danson 2008: 50) with a call for much more pro-active policy initiatives to maximise, embed and harness these valuable human resources. To prevent under-utilization of skills, language training is mentioned as playing a key role along with career guidance, proper recognition of qualifications and work experience programmes. These are initiatives that are highly relevant to the Faroese context but also of course point to a more global trend. Such policy measures were identified by the research participants themselves: the challenge of language learning-mainly the limited access to courses in Faroese at different competence levels and in different geographical regions, limited access to language resources (e.g. television and other media), and limited opportunities for language learning in the workplace-were the central themes they raised in our conversations. As a consequence of these obstacles, language becomes the main barrier to accessing professional job opportunities in the local labour market. Therefore, the implications of underemployment and under-utilization of professional skills are a major concern, especially as not using these over an extensive period may lead to potential de-skilling. This may be understood in the sense that if a worker has not used his/her professional skills for several years, he/she may be put at a disadvantage in terms of competing with others for jobs within his/her field. This can generate long term negative labour market effects of hysteresis (lowered likelihood of getting a job) (Hargreaves Heap 1980; Cross 1993) and employment scarring, (the effects of a period of unemployment on future prospects of employment) (Nunley et al. 2016).

The proportion of workers of migrant origin in the three research sites visited is approximately $40 \%$ and this is probably not atypical. A tentative conclusion is that migrants to the Faroes are filling gaps in low skilled occupations such as cleaning and fish-factory work. Issues of pay appear to be a reason why some workers stay on in these entry level jobs: some reported that they earn significantly more in these positions than in skilled work in their country of origin. When asked about future aspirations, staying on in blue-collar jobs was not on their list of priorities. It could be argued, the Faroes "needs a proper system of 'aftercare' in order to embed migrant labour, developing this tremendous resource by seeking ways of integrating these workers into local economies and by ensuring that workers maximise the utilisation of their skills (....) within the labour market", (as Brown and Danson 2008: 48 have suggested in the Scottish context).

Nevertheless, the Faroes currently are almost totally dependent on their fish-processing industry (Faroeislands.fo 2017) and migrant workers are essential to maintaining production and income generation for enterprises, workers and the state. This raises issues for the economy and society as local workers alone cannot meet the labour requirements of these fish processors, even though this is an increasingly capital-intensive sector (OECD 2011). The contradictory pressures of realising the 
potential of the migrant workers by satisfying their employment ambitions on the one hand and of ensuring a workforce for this basic export industry on the other revolves around this sociolinguistic challenge. Understanding the lived experiences of these workers can provide valuable insights for policy makers and planners which can in turn inform institutional policy in the wider society. Our study shows that there is a clear discrepancy between what adult migrants require in terms of language learning needs and what is available at institutional level. Such lack of provision, particularly in peripheral areas, contributes to inequalities and therefore acts as a potential barrier to social mobility and career advancement.

Acknowledgements We wish to acknowledge the support of the Faroese Research Council https://www. gransking.fo/en/ for funding the project New Times, 'New Speakers' of Faroese and the Sociolinguistics of Labour market Integration: Challenges and Opportunities (grant number 0229) which led to the writing of this paper. This work is linked to a larger project on 'new speakers' funded under th auspices of the European Cooperation in Science and Technology as part of EU COST Action IS1306 entitled 'New Speakers in a Multilingual Europe: Opportunities and Challenges' https://www.cost.eu/actions/IS130 6/\#tabs|Name:overview.

Open Access This article is distributed under the terms of the Creative Commons Attribution 4.0 International License (http://creativecommons.org/licenses/by/4.0/), which permits unrestricted use, distribution, and reproduction in any medium, provided you give appropriate credit to the original author(s) and the source, provide a link to the Creative Commons license, and indicate if changes were made.

\section{References}

Barakos, E., \& Unger, J. (2016). Discursive approaches to language policy. Basingstoke: Palgrave Macmillan.

Bermingham, N., \& Higham, G. (2018). Immigrants as new speakers in Galicia and Wales: Issues of integration, belonging and legitimacy. Journal of Multilingual and Multicultural Development, 39,(5), 394-406.

Bermingham, N., \& O'Rourke, B. (2018). Language awareness among "new speakers" in a multilingual classroom. In C. Hélot, C. Frijns, K. Gorp \& S. Sierens (Eds.), Multilingual classrooms in Europe: From theory to practice, (pp. 143-168). Boston/Berlin: De Gruyter Mouton.

Bhugra, D. (2004). Migration, distress and cultural identity. British Medical Bulletin, 69(1), 129-141.

Block, D. (2004). Second language identities. London: Bloomsbury.

Blommaert, J. (2010). The sociolinguistics of globalization. Cambridge: Cambridge University Press.

Blommaert, J., Kelly-Holmes, H., Lane, P., Leppänen, S., Moriarty, M., Pietikäinen, S., \& PiirainenMarsh, A. (2009). Media, multilingualism and language policing: An introduction. Language Policy, 8(3), 203-207.

Bourdieu, P. (1977). The economics of linguistic exchange. Social Science Information, 16(6), 645-668.

Bourdieu, P. (1991). Language and symbolic power. Cambridge: Polity Press.

Breger, R., \& Hill, R. (1998). Cross-cultural marriage: Identity and choice. Oxford: Berg Publishers.

Britain, D. (2012). Countering the urbanist agenda in variationist sociolinguistics: Dialect contact, demographic change and the rural-urban dichotomy. In S. Hansen, C. Schwarz, P. Stoeckle, \& T. Streck (Eds.), Dialectological and folk dialectological concepts of space (pp. 12-20). Berlin: Mouton De Gruyter.

Britain, D. (2016). Conceptualisations of geographic space in linguistics. In A. Lameli, R. Kehrein, \& S. Rabanus (Eds.), Language and space: An international handbook of linguistic variation (Vol. 2, pp. 69-97)., language mapping Berlin: De Gruyter Mouton.

Brown, R., \& Danson, M. (2008). Fresh talent or cheap labour? Accession State migrant labour in the Scottish Economy. Scottish Affairs, 64, 37-52. 
Cabral, E., \& Martin-Jones, M. (2017). Moving north, navigating new work worlds and re-mooring: Language and other semiotic resources in the migration trajectories of East Timorese in the UK. In C. Kerfoot \& K. Hyltenstam (Eds.), Entangled discourses: South-north orders of visibility (pp. 79-98). Abingdon, Oxon: Routledge.

Caglitutuncigil, T. (2018). Between myth and reality: Language classrooms in Spanish and Catalan social integration programmes. Journal of Multicultural and Multilingual Development, 39, 431-444.

Canagarajah, S. (2006). Ethnographic methods in language policy. In T. Ricento (Ed.), An introduction to language policy: Theory and method (pp. 153-169). Malden, MA: Blackwell.

Christensen, K. (2016). Negotiating cultural differences. In K. Christensen \& I. Guldvik (Eds.), Migrant care workers. Searching for new horizons (pp. 123-146). Abingdon: Routledge.

Cooper, R. L. (1989). Language planning and social change. Cambridge: Cambridge University Press.

Cross, R. (1993). On the foundations of hysteresis in economic systems. Economics and Philosophy, 9(1), $53-74$.

Danson, M., \& de Souza, P. (Eds.). (2012). Regional development in Northern Europe: Peripherality, marginality and border issues. Abingdon, Oxon: Routledge.

Danson, M., \& Jentsch, B. (2012). International migration and economic participation in small towns and rural areas: Cross-national evidence. Towards a policy paper. Migration Letters: Social Mobility and Migration. Multidisciplinary Perspectives, 9(15), 215-224.

Darquennes, J. \& Soler, J. (Eds.) (2019). New speakers' and language policy research: thematic and theoretical contributions to the field. Language Policy. Special Issue.

Del Percio, A. (2015). New speakers on lost ground in the football stadium. Applied Linguistics Review, $6(2), 261-280$.

Del Torto, L. M. (2008). Once a broker, always a broker: Non-professional interpreting as identity accomplishment in multigenerational Italian-English bilingual family interaction. Multilingua, 27, 77-97.

Donner, S. (2015). The legacy of migration in response to climate stress: Learning from the Gilbertese resettlement in the Solomon Islands. Natural Resources Forum, 39, 191-201.

Duchêne, A. (2011). Neoliberalism, social inequalities, and multilingualism: The exploitation of linguistic resources and speakers. English translation of Néolibéralisme, inégalités sociales et plurilinguisme: 1'exploitation des ressources langagières et des locuteurs. Langage \& Société, 136, 81-108.

Duchêne, A., Moyer, M., \& Roberts, C. (Eds.). (2013). Language, migration and social inequalities. Bristol: Multilingual Matters.

Faroeislands.fo (2017). A fishing nation with proud traditions. https://www.faroeislands.fo/economybusiness/fisheries/. Accessed 16 Dec 2017.

Fishman, J. A. (1991). Reversing language shift. Clevedon: Multilingual Matters.

Føroya Landsstýri (2013). Heildarætlan - Fólkalyting og fólkavøkstur. Vinnumálaráðið.

Gal, S. (1989). Language and political economy. Annual Review of Anthropology, 18, 345-367.

Gonçalves, K. (2013). Conversations of intercultural couples. Berlin: Mouton de Gruyter.

Gonçalves, K., \& Schluter, A. (2017). "Please don't leave any notes for the cleaning lady, as many do not speak English fluently": Policy, power, and language brokering in a multilingual workplace. Language Policy, 16, 241-265.

Halonen, M., Ihalainen, P., \& Saarinen, T. (Eds.). (2014). Language policies in Finland and Sweden: Interdisciplinary and multi-sited comparisons. Bristol: Multilingual Matters.

Hargreaves Heap, S. (1980). Choosing the wrong 'natural' rate: Accelerating inflation or decelerating employment and growth? Economic Journal, 90, 611-620.

Hayfield, E. A. (2017). Exploring the transnational realities in the lives of Faroese youngsters. Nordic Journal of Migration Research, 7(1), 3-11.

Heller, M. (1995). Language choice, social institutions and symbolic domination. Language in Society, 24(3), 373-405.

Heller, M. (2007). Bilingualism as ideology and practice. In M. Heller (Ed.), Bilingualism: A social approach (pp. 1-22). Basingstoke: Palgrave Macmillan.

Heller, M. (2008). Doing ethnography. In L. Wei \& M. Moyer (Eds.), Research methods in bilingualism and multilingualism (pp. 249-262). Malden: Blackwell.

Heller, M. (2011). Paths to post-nationalism: A critical ethnography of language and identity. Oxford: Oxford University Press.

Hewitt, R. (2012). Multilingualism in the workplace. In M. Martin-Jones, A. Blackledge, \& A. Creese (Eds.), Routledge handbook of multilingualism (pp. 267-280). Abingdon, Oxon: Routledge. 
Holm, E. (2003). Linguistic revitalization in the Faroes: From vernacular towards national status. In L. Huss, A. Grima, \& K. King (Eds.), Transcending monolingualism: Linguistic revitalization in education. Lisse, The Netherlands: Swets \& Zeitlinger.

Hornberger, N. H. (Ed.). (1996). Indigenous literacies in the Americas: Language planning from the bottom up. Berlin: Mouton.

Hornberger, N. H. (2015). Selecting appropriate research methods in LLP research: Methodological rich points. In F. M. Hult \& D. C. Johnson (Eds.), Research methods in language policy and planning. A practical guide (pp. 9-20). Oxford: Wiley Blackwell.

Hornberger, N. H., \& Johnson, D. C. (2007). Slicing the onion ethnographically: Layers and spaces in multilingual language education policy and practice. TESOL Quarterly, 41, 509-532.

Hovgaard, G., \& West, H. (2003). Rekruttering av høgt útbúnari arbeiðsmegi til fiskivinnuna. Arbeiðsrit nr. 4/2003. Granskingardepilin fyri Økismenning.

Hult, F. M. (2010). Analysis of language policy discourses across the scales of space and time. International Journal of the Sociology of Language, 202, 7-24.

Hult, F. M., \& Johnson, D. C. (2015). Research methods in language policy and planning. A practical guide. Oxford: Wiley Blackwell.

Hymes, D. (1972). Models of the interaction of language and social life. In J. J. Gumperz \& D. Hymes (Eds.), Directions in sociolinguistics: The ethnography of communication (pp. 35-71). New York: Holt, Rinehart \& Winston.

Irvine, J. T., \& Gal, S. (2000). Language, ideology, and linguistic differentiation. In P. V. Kroskrity (Ed.), Regimes of language: Ideologies, polities, and identities (pp. 35-84). Santa Fe: School of American Research Press.

Island Studies Journal (2014). Special Issue: Islands and the Borders of Southern Europe, 9, 1.

Jacobsen, J. í L. (2012). Arligt talt, who cares? En sociolingvistisk undersøgelse af holdninger til og brug af importord og aflasningsord i farøsk. Oslo: Novus Forlag.

Jaffe, A. (2012). Collaborative practice, linguistic anthropological enquiry and the mediation between researcher and practitioner discourses. In S. Gardner \& M. Martin-Jones (Eds.), Multilingualism, discourse and ethnography (pp. 334-352). New York: Routledge.

Johannesarson, T. (2018). Málmenning-eisini á miðnámi. Miðnámsrit, 15, 22-23.

Johnson, D. C. (2009). Ethnography of language policy. Language Policy, 8, 139-159.

Johnson, D. C. (2013). Language policy. Basingstoke: Palgrave Macmillan.

Johnson, D. C. (2017). Critical ethnography of language policy: A semi-confessional tale. In M. MartinJones \& D. Martin (Eds.), Researching multilingualism: Critical and ethnographic perspectives (pp. 105-120). Abingdon, Oxon: Routledge.

King, R. (2009). Geography, islands and migration in an era of global mobility. Island Studies Journal, 4(1), 53-84.

Knudsen, K. J. (2010). Language use and linguistic nationalism in the Faroe Islands. International Journal of Multilingualism, 7(2), 128-146.

Lamarre, P. (2013). Catching "Montréal on the Move" and challenging the discourse of unilingualism in Quebec. Antropologica, 55(1), 41-56.

Lazarevic, V., Rafaelli, M., \& Wiley, A. (2014). Language and non-linguistic brokering: Diversity of experiences of immigrant young adults from Eastern Europe. Journal of Comparative Family Studies, 4, 517-535.

Martin-Jones, M., \& da Costa Cabral, I. (2018). The critical ethnographic turn in research on language policy and planning. In J. W. Tollefson \& M. Pérez-Milans (Eds.), The Oxford handbook of language policy and planning. Oxford: Oxford University Press.

Martin-Jones, M., \& Martin, D. (Eds.). (2017). Researching multilingualism: Critical and ethnographic perspectives. Abingdon, Oxon: Routledge.

McCarty, T. (Ed.). (2011). Ethnography and language policy. New York \& London: Routledge.

McCarty, T. (2015). Ethnography in language planning and policy research. In F. M. Hult \& D. C. Johnson (Eds.), Research methods in language policy and planning: A practical guide (pp. 81-93). Oxford: Wiley Blackwell.

Medda-Windisher, R., Danson, M., Morén-Alegret, R., \& Gaye, M. (2012). Editorial introduction, social mobility and migration. Multidisciplinary perspectives. Migration Letters, 9(3), 193-199.

Mentamálaráðið (Ministry of Education, Research and Culture). (2007). Málmørk-Álit um almennan málpolitikk. Tórshavn: Mentamálaráðið (Ministry of Education, Research and Culture).

Mitchinson, J. (2012). Danish in the Faroe Islands: A post-colonial perspective. Unpublished PhD thesis. University College London. 
Moll, L., Amanti, C., Neff, D., \& Gonzalez, N. (1992). Funds of knowledge for teaching: Using a qualitative approach to connect homes and classrooms. Theory into Practice, 31(2), 132-141.

Norton, B. (2000). Identity and language learning. Harlow: Pearson Education Limited.

Nunley, J., Pugh, A., Romero, N., \& Seals, A. (2016). The effects of unemployment and underemployment on employment opportunities. Results from a correspondence audit of the labor market for college graduates. ILR Review, 70(3), 642-669.

O'Rourke, B., \& Pujolar, J. (2015). New speakers and processes of new speakerness across time and space. Applied Linguistics Review, 6(2), 145-150.

O’Rourke, B., Pujolar, J., \& Ramallo, F. (2015). New speakers of minority language: The challenging opportunity-Foreword. International Journal of the Sociology of Language, 231, 1-20.

O'Rourke, B., \& Ramallo, F. (2013). Competing ideologies of linguistic authority amongst new speakers in contemporary Galicia. Language in Society, 42, 287-305.

OECD. (2011). OECD territorial reviews: NORA Region. Paris: OECD.

Perumal, N. (2018). "The place where I live is where I belong": Community perspectives on climate change and climate-related migration in the Pacific island nation of Vanuatu. Island Studies Journal, $13(1), 45-64$.

Petersen, H. P. (2006). Føroyskt-danskt málsamband. Athall, tillaging, eingangstillaging og málbygging. (Convergence, accommodation and language building in Faroese). Fróðskaparrit, 54, 8-20.

Petersen, H. P. (2010). The dynamics of Faroese-Danish language contact. Heidelberg: Winter-Verlag.

Pietikäinen, S., Kelly Holmes, H., Jaffe, A., \& Coupland, N. (2016). Sociolinguistics from the periphery: Small languages in new circumstances. Cambridge: Cambridge University Press.

Piller, I. (2002). Bilingual couples talk. Amsterdam: John Benjamins.

Piller, I. (2016). Linguistic diversity and social justice. An introduction to applied sociolinguistics. Oxford: Oxford University Press.

Piller, I., \& Lising, L. (2014). Language, employment and settlement: Temporary meat workers in Australia. Multilingua, 33(102), 35-59.

Pujolar, J. \& Puigdevall, M. (2015). Linguistic 'Mudes': How to become a new speaker in Catalonia. International Journal of the Sociology of Language, 231, Special Issue on New Speakers of European Minority Languages).

Ricento, T. K., \& Hornberger, N. H. (1996). Unpeeling the onion: Language planning and policy and the ELT professional. TESOL Quarterly, 30(3), 401-428.

Roberts, C. (2013). The gatekeeping of Babel: Job interviews and linguistic penalty. In A. Duchêne, M. Moyer, \& C. Roberts (Eds.), Language, migration and social inequalities (pp. 81-94). Bristol: Multilingual Matters.

Samuelsen, I. (2017). Faroe Islands heading for dream target-50,000 citizens. Nordic Labour Journal. http://www.nordiclabourjournal.org/i-fokus/in-focus-2017/the-100-year-wave-hitting-nordic-labou r-market/article.2017-01-30.7365890332.

Sandøy, H. (1992). Faroese a minority language or a national language? In G. Blom, P. Graves, A. Kruse, \& T. Thomsen (Eds.), Minority languages: The Scandinavian experience (pp. 57-73). Report 17. Oslo: Nordic Language Secretariat.

Simpson, J., \& Bradley, J. (2017). Communication in the contact zone: The TLANG project and ESOL. Working Papers in Translanguaging and Translation (WP. 24) (http://www.birmingham.ac.uk/gener ic/tlang/index.aspx).

Simpson, J., \& Whiteside, A. (2015). Adult language education and migration: Challenging agendas in policy and practice. Abingdon, Oxon: Routledge.

Skarði, B. (2018). Føroyskt sum fremmendamál. Miðnámsrit, 16, 13-17.

Strömmer, M. (2016). Affordances and constraints: Second language learning in cleaning work. Multilingua Journal of Cross-Cultural and Interlanguage Communication, 35(6), 697-723.

Thomas, G. (1991). Linguistic purism. London: Longman.

Thuesen, F. (2017). Linguistic barriers and bridges: Constructing social capital in ethnically diverse lowskill workplaces. Work, Employment \& Society, 31(6), 937-953.

Útlendingastovan. (2016). New to the Faroe Islands. Practical information from public agencies. Útlendingastovan-The Faroese Immigration Office. www.immigration.fo.

Tse, L. (1996). Language brokering in linguistic minority communities: The case of Chinese- and Vietnamese-American students. The Bilingual Research Journal, 20(3), 485-498.

Weyhe, E. (2015). Færøsk gennem to hundrede år. In H. Sandøy (Ed.), Talemål etter 1800. Norsk i jamføring med andre nordiske språk (pp. 409-432). Oslo: Novus Forlag.

Wodak, R., \& Meyer, M. (Eds.). (2016). Methods of critical discourse studies (3rd ed.). London: SAGE. 
Woolard, K. (1998). Language ideology as a field of inquiry. In B. Schieffelin, K. Woolard, \& P. Kroskrity (Eds.), Language ideologies: Practice and theory (pp. 3-49). New York: Oxford University Press.

Woolard, K. A. (2016). Singular and plural: Ideologies of linguistic authority in 21st century Catalonia. Oxford: Oxford University Press.

Publisher's Note Springer Nature remains neutral with regard to jurisdictional claims in published maps and institutional affiliations.

Anna-Elisabeth Holm is a PhD candidate at Heriot-Watt University. In her research, Elisabeth focuses on migrants in the Faroe Islands and the sociolinguistics of labour market inclusion. She holds a Masters degree in English from Copenhagen University and an MA in Language Studies (sociolinguistics) from Lancaster University. For many years she taught English in an uppersecondary school in Tórshavn and more recently worked as an international coordinator at the University of the Faroe Islands. Her research interests include 'small' and minoritized languages, sociolinguistic ethnography, language policy, multilingualism in the periphery, language and globalization, language and migration, and adult migrant language education.

Bernadette O'Rourke is Professor of Sociolinguistics at the University of Glasgow. Her research focuses on the role of language in the construction of social difference and social inequality, drawing on theoretical frameworks and concepts in the area of sociolinguistics and the sociology of language. She is author of Galician and Irish in the European Context, Palgrave (2011) and co-author of the Handbook of Minority Languages and Communities, Palgrave (2019). She was Chair of COST Action (IS1306) New Speakers in a Multilingual Europe between 2013 and 2017.

Mike Danson is Emeritus Professor of Enterprise Policy and Director of Doctoral Programmes, HeriotWatt University. He has a DLitt in Regional Economic Development and Regional Development Agencies. Mike has researched and published on urban and regional development, employability, economic impact of Gaelic, island and rural economies, community renewal, poverty and inequality. He has advised governments and parliaments, national and international organisations including the European Commission, OECD, trade unions and community bodies. Mike is Treasurer of the Academy of Social Sciences, Chair of Citizen's Basic Income Scotland and the jimmy Reid Foundation. 